\title{
Al-Muwathanah Concept for non Muslims in Islamic majority Countries Siyasah Fikih Perspective
}

\author{
Lukman Arake ${ }^{* 1}$ \\ ${ }^{*}$ Institut Agama Islam Negeri (IAIN) Bone,Sulawesi-Selatan,Indonesia \\ *e-mail: ${ }^{* 1}$ fawwazlukman@gmail.com
}

\begin{abstract}
The Islamic priests do not use the word of minority (akalliyah) in the literature of classical Islamic jurisprudence when they talk about the existence of non-Muslims in Islamic countries, but they use the term of ahluzzimmah. Their reason not to use that term is because Islam itself does not distinguish the rights and obligations between Muslims or nonMuslims who live in a country, except those closely related to religious issues. This was caused by the actualization concept from one of religion rule "lahum maa lana wa alaihim ma alaina" which means: they have rights and obligations as Moeslems. Despite our scholars do not use the term of minority in their own intellectual tradition, the term has become popular especially in a concept of writing process that cause the using of these terms is valid.
\end{abstract} Keywords - Al-Muwathanah, Non Muslim minority, Islamic Society, Siyasah
Jurisprudence

\section{INTRODUCTION}

In the Islamic world, the term minority is one of the new terms after the friction between the Ottoman dynastic government in Turkey with several European superpowers. A group of countries in Europe have used this term for certain groups which are considered to be far smaller in number than other groups in the Ottoman dynasty which came to be known as 'eastern issues' [1] while the minority terms in the modern era are nothing but a form of earthing developed by westerners who then sneak into the Islamic world through the friction of different civilizations and social cultures. Nevertheless, the existence of non-Muslims in the community of modern Islamic society is something that cannot be denied. That is, this problem needs a serious study of the extent to which Islam gives away their rights. Therefore, in this paper we will explain transparently about the extent to which Islam views their existence and what rights they must obtain from a country where the majority of the population is Muslim. 


\section{Non-Muslims in the Middle of Islamic Society}

It is undeniable that at present there is not a single country in the world where the majority of Muslims are not found in it as non-Muslims. The Qur'an itself has legitimated their existence as a community that is often referred to as the Ahlul Kitab [2]. Their existence in the midst of Islamic societies throughout history as part of the elements of society that received protection and rights from the Islamic government allowed them to live in peace and peace with the Muslims. Therefore, in Islamic literature it is taught that the state is obliged to be fair to them without the slightest discrimination. In addition, in the regulation of their lives, especially those relating to the practice of religious values that they believe in, the state is obliged to provide full support to them as long as this does not conflict with Islamic religious norms.

Here it is necessary to explain the views of Islamic scholars regarding the legal issue of the entry of non-Muslims into a country with a majority Muslim population. If a country with a predominantly Muslim population accepts non-Muslims who sometimes become local citizens as is the case in the current era where many people move from state to state, then Islam also has a system tself about this, especially non-Muslims who enter the territory of the Islamic government or are often called darul Islam or Islamic countries.

Islamic scholars view that non-Muslim foreigners (not ahluzzimmah) include non-Muslim harb [3] or muahad [4]. When both enter the Islamic government, they are considered to have received temporary security guarantees from the government. This security guarantee is similar to the visa entry that a citizen gets when visiting another country in order to get security guarantees from the local government while they are in the country.

On the other hand, the entry visa or so-called al-Amnu al-Muakkat in Islamic literature is usually obtained from the head of state or an agency appointed by the government to be responsible for the problem. That is because the head of state in the context of Islamic Jurisprudence is the person most responsible for the stability and security of the state in accordance with the rules of Islamic law that: Tasarrufu al-Imami ala ar-Raiyah manutun bi alMaslahah. This means that any government policy towards its people must be based on benefit.

The system of interaction between one country and a non-citizen while at the same time acknowledging them as an institution is something legitimized by Islam which was later adopted by Europeans in the Middle Ages due to open trade relations, as well as cooperation between European countries and the world Islam, especially Arab countries through Andalusia or Spain and the waters of the white sea coast, also some areas in Italy, especially after the crusade [5]. If Islamic scholars consider non-Muslims allowed to enter the Islamic land, but they differ in terms of implementation of how much time they can stay or live in the land of Islam itself. The majority of scholars consider that non-Muslims who enter Muslim countries may not stay for up to one year. If they stay for one year, they are obliged to pay jizyah [6]. 
On the other hand, there are those who say that non-Muslims who enter the Islamic government area may stay as they wish but on the condition that they obtain approval from the local government [7]. In addition, the Islamic government has the right to cancel their residence permit if it does not comply with applicable regulations, or committing criminal acts that are detrimental to and disturbing the stability of the country. Departing from these two interpretations, it can be concluded that non-Muslims who enter the Islamic land then live more than the permit granted by the government and do not leave the country are considered an indication of the desire to become an Islamic citizen, which is then called ahluzzimmah.

In addition, a non-Muslim male who gets permission from the Islamic government to enter the Islamic area and then convert to Islam, or remain in his religion but he becomes an ahluzzimmah, his wife and small children will follow the status of their parents, namely becoming citizens of Islam. This happens because in Islamic literature, mothers and fathers are equalized so that both of their children can be followed by citizens even if their children are born outside the territory of Islamic government.

Another case with boys whose status is an adult. To get citizens like their parents they have to go through the process as their parents did. Regarding the issue of the status of a child whose parents are different citizens in the conventional citizenship law there are differences between one country and another. For example the citizenship laws of the Arab Republic of Egypt in 1926 and 1929 have little in common with what has been carried by classical Islamic scholars about allowing a child to follow one of his parents who are citizens of the state of Egypt even if the child was born outside the country in question. This indicates that what was initiated by the classical Islamic scholars related to the naturalization of citizenship had previously been explained transparently. While in conventional law, the problem was only known at the end of the 18 th century $\mathrm{AD}[8]$.

\title{
Non-Muslim, Naturalization and the Concept of al-Muwathanah
}

The existence of non-Muslims in a Muslim-majority country is still a problem that is contested especially in this modern era where some people consider that their existence as part of a society that lives marginalized. Is it true that Islam views them like that? Or does Islam position them as equals to other Muslims, even though in Islamic literature they are known as ahluzzimmah? Actually the term ahluzzimmah for non-Muslims who live in a predominantly Muslim country is only mentioned twice in the Qur'an, namely, verse 8 surah al-Bakarah and verse 10 surah at-Taubah. Apart from these two verses, the Qur'an does not characterize non-Muslims except with sentences such as the Ahlul Kitab or Almusyrikun. In the hadith of the Prophet, we also encounter this phrase for example, narrated by Amru bin Syuaib (died $128 \mathrm{H}$ ) from his father and grandfather that the Prophet said: "Muslims are all the same, besides those (Muslims) trying to get protection from people Muslim " [9].

\author{
IJoASER,Volume 2,Issue 1,March,2019 \\ DOI: 10.33648 \\ Copyriht: STAI Al-Furqan Makassar,Indonesia \\ Content License: CC-BY-SA
}


In addition, the Prophet used many of these sentences in official documents or letters sent to several non-Muslim kings as reported by Abu Ubaid (157-224 H) that the Prophet had sent a letter to al-Mundhir bin Sawi. In the letter it says: "Greetings to you, verily I praise God for you, there is no god but Allah. Furthermore, whoever performs prayers like us and faces our Qibla and eats our slaughter is a Muslim who will get the responsibility of Allah and His Messenger ". Departing from these two fragments, said ahluzzimmah in the Qur'an and the hadith as a word to express the existence of non-Muslims in a Muslim community.

Even though such expressions are found in the Koran or in the hadith of the Prophet, they have also previously become part of the language of interaction of the Arabic tribes before the advent of Islam. The jahiliyah Arabs themselves are accustomed to using the term as a language of peace in establishing a fraternity and help when one group comes to another group to be given assistance especially during a war [10]. The concept of ahluzzimmah in Islam is related to the conditions of the spread of Islamic da'wah itself. That is, when there is a dispute or war between the Islamic government and non-Islamic government then the Islamic army managed to conquer the enemy then at that time the Islamic government will give two choices to the population of the country, if they do not convert to Islam it means they remain in their religion with one consequence that at that time an agreement was reached which became known as ahluzzimmah.

Those ahluzzimmah are required to pay jizyah to the Islamic government with a guarantee that they will get security protection. Thus, it can be concluded that the expansion of Islamic territory is one of the causes of the birth of this term in history. However, it should be noted that the term ahluzzimmah is actually not something made up by Muslims for nonMuslims, because in history it is stated that the Romans had also previously assumed that a person's existence in a government did not come out of three possibilities. First, the native population; second, Latinos and third are foreigners. The Romans thought that the foreigners were enemies, and besides the Barbarians, their wealth was considered lawful to be taken, even that their blood was legal according to their beliefs [11].

Ahluzzimmah in classical Islamic discourse is considered as an element that has citizenship rights. They are citizens, especially after the recognition of citizenship laws in which the international community is divided into several citizens according to the place where they live and provide patronage as a form of defense against the state that makes itself part of it. NonMuslims who live in the midst of Islamic society have rights and obligations, although it must be explained that citizenship or nationality both in conventional legal language and in political language is one of the terms that were only known at the end of the 18 th century AD which means someone's favor in certain countries although multiracial. The International Court of Justice on April 6, 1951 explained that citizens were: "One form of legal linkage that occurs on the basis of social and community relations contracts facing life and mutual benefit with a provision that rights and obligations are for all". 
Based on the explanation above, it can be understood that nationality is a form of legal relationship between a person and a certain country. That connection is then used as the only reason for someone to get protection in the midst of the international community. Therefore, someone who has no citizenship is not entitled to protection. That is why until now there has been no legal method that guarantees protection to someone in the international community except after the citizenship is known. Nationality is a form of essential connection that connects a person with a certain country so that if it is not fulfilled then he will not be able to obtain his rights, because it is a matter determined by the state, because it is the state that has absolute authority to give citizenship to someone [12] .

Some international agreements state that each country has the authority to regulate the issue of citizenship as stated in the first point of the Lahai agreement signed on April 12, 1930, especially concerning the issue of legal disputes relating to citizenship issues that: "Every country has the right to determine who belongs to its citizens in accordance with the laws of the country " [13].

Conventional law which discusses citizenship turns out in classical Islamic fikhi literature has also been explained about one's relationship with the state even though it does not use the term nationality. The scholars have explained about a person's relationship with the state and the reasons for the breakup. In this way, this certainly makes a point of equality between the concept of citizenship in Islam and international law governing citizenship or the termination of it [14]. In classical Islamic discourse, brilliantly explained about the context of ahluzzimmah where it is a form of transaction that takes place between the government with a non-Muslim or more, with a stimulation that they will get their rights as well as Muslims as long as they pay jizyah as a form of obligation to the state to get security protection and so on [15]. If in Islam the transaction is a government authority as institutions that are obliged to regulate them as well as their children who are born later, it is not wrong to say that it is the same thing in the context of existing international law regarding the permissibility of a country to accept certain people who wish to become agian from him.

Islam sees non-Muslims who live in the midst of Islamic society having the same status especially those relating to citizenship issues. They are part of a country that has rights and obligations. This can be seen from the assertion of one of the classical Islamic scholars, Imam Assarakhsy: "Indeed, nonMuslims who have a connection with the Islamic government (akduzzimmah) are part of the population of our country namely darul Islam" [16]. The word addar in this context is alwathan which means the country . That is why they are considered allied with Muslims in terms of the homeland. Moreover, when the Prophet signed a treaty with non-Muslim groups from several Arab tribes and Jews, he emphasized in the agreement: "Truly the Jews of the Awf are the ummah with the believers. For the Jews of their religion, and for the Muslims of their religion, helping each other except 
those who do wrong and commit sins then surely he does not destroy except himself and his family " [17].

In this fragment, the Prophet has positioned non-Muslims as part of the state community as well as Muslims as long as they are consistent with the values of peace and interact well with Muslims. This is a reality that they are with the Muslims is a unit that gets its protection and rights from the state. It's just that it needs to be explained here that specifically in Islam there are differences regarding the basic citizenship between Muslims and nonMuslims. The basis of citizenship for Muslims is their creed, while the principle of citizenship for non-Muslims is akduzzimmah[18]. If every law in force in any country that exists today can provide jurisdiction, someone may obtain citizenship from a particular country after fulfilling the applicable qualifications in the country for example the person has lived in the country referred to by a certain time such as 10 years as it is currently in effect in several Arab countries such as the Arab republic of Egypt, the Arab republic of Libya and the Arab republic of Sudan, then in the Islamic legal literature long before this problem was explained details.

\section{Jizyah and its Relevance to the Concept of al-Muwathananh}

As has been explained that non-Muslims living with Muslims in one country are all considered elements of the nation and state. It is this point which then requires us to reorient to clarify some of the problems that many people misunderstand, namely the problem of jizyah. Jizyah in its etymological sense comes from the word al-Jaza which means reply or reward. Besides that the word jizyah can also mean something that is collected from non-Muslims. While the epistemological understanding is the amount of money or assets that are paid regularly by non-Muslims who live in the midst of an Islamic community with a consequence that they get their rights such as protection of security from the state [19]. Among Islamic scholars there is a different interpretation of time he requires jizyah. Some of them said that it was prescribed in the 8th year of $\mathrm{H}$. While the others said in the 9 th year of $\mathrm{H}$ [20]. While the legal basis is the word of God which means: "Fight those who do not believe in Allah and neither (nor) towards days later, and they do not forbid what is forbidden by Allah and His Messenger and do not have a religion with the true religion (the religion of Allah), (ie people) that the Book gives them, until they pay jizyah in their obedience while they obey in submission ". (Surat Attaubah: 29).

The scholars agree that this jizyah is required of the Ahlulkitab, namely Jews, Christians and people who are considered to have a holy book like the Majuzi people. The obligation is based on the word of God that was mentioned earlier. In addition, it also argues on the hadith narrated by Abdurrahman bin Auf (died $32 \mathrm{AH}$ ) that the Prophet had required jizyah of the Majuzi people by saying: "Equate them with the people of the book" [21].Non-Muslims who are required jizyah as described by the scholars only to men who have a source of income. As for children, women and parents who do not have jobs are not required of them.

From this commitment it can be understood that jizyah paid by them is not a form of negative encumbrance let alone be considered as repression. 
However, it has certain objectives including the guarantee of security and protection from the state for them; and released from the obligation to defend the country in the event of chaos. So it is clear that the aim is to maintain their existence in the midst of Islamic society with the preservation of civil rights, human rights and their political rights and the absence of coercion for them to convert to Islam. With this indication, Ali bin Abi Talib said: "NonMuslims pay jizyah so that their blood is the same as the blood of Muslims, and their wealth is the property of Muslims" [22].

Because jizyah is a form of imposition of non-Muslims, it is the authority of the government and not Muslims in general, because the problem is so closely related to the state's political conditions and policies that the law may be subject to change depending on the country's conditions. Therefore the scholars give an explanation of this: "It is mandatory for the government to instruct every non-Muslim from Ahlulkitab to pay jizyah so that they can settle in an Islamic country. And the government in this case is obliged to do two things. First, look after them. Second, provide protection to them so that they feel safe and secure "[23].

If in the discourse of Islamic thought, non-Muslims who live in the midst of the Islamic community are considered citizens, it is very natural that the government adopts an administrative system which then becomes imperative for them to pay jizyah which can be harmonized with the obligatory charity of Muslims so.

The government can fulfill its obligations. Although the scholars have various interpretations of the reasons for the obligation of jizyah on nonMuslims, whether because it is considered as a substitute for the burden to defend the country, or because they are still given the freedom to believe in their religion, or because they get protection from the state. What is certain is that the payment can be interpreted as a reward for them and not as harassment because what they pay is nothing but for them to get protection from the state; and in this case the state will be more free to allocate the results of the jizyah to the public interest such as infrastructure development and so on. This is the core of the relationship between the meaning of citizenship with the jizyah that they are presenting to the government.

The existence of this system in Islam is self-recognized by Western Orientalists as Sirt Thomas Arnold said: "The payment of jizyah is very simple and judicial is not burdensome compared to the burden borne by Muslims, namely compulsory military service to defend the country, while for non-Muslims not obligatory "[24]. On another occasion, Sirt Thomas Arnold also said that the payment of jizyah by non-Muslims was not intended to harass them because they did not convert to Islam, but they did all that because they were not required to join military service. In addition, they pay jizyah so that they get security protection from the state or from Muslims [25]. The relevance of jizyah to non-Muslim citizenship is built on the basis of the obligation of every citizen to enter the military to defend the country in the event of riots or war. In this case, Islamic law does not burden them to 
become part of the military forces so that they are obliged to pay jizyah. The payment was considered as a substitute for compulsory military service, and it was only collected from non-Muslims who were able to take up arms for use in military operations.

Such things in contemporary history turned out to be not only imposed on non-Muslims, but also on Muslims as happened in Egypt until around the middle of the 20th century AD where anyone who did not wish to become a member of the military in order to obtain approval from the government, but they were asked for a ransom called badlul jihadiyah or a form of payment so that they would not

Demanded by the state to become a member of the military [26]. Jizyah in Islam has no other purpose except to lead to two important aspects of society:

\section{First, to cover social inequalities}

If a Muslim in Islam is required to issue zakat as a form of worship based on the word of God, which means: "And establish prayer, pay zakat and ruku'lah along with those who bow" (Qs. Al-Baqarah: 43). So it is very natural that even non-Muslim communities are burdened by the state to set aside some of their assets in order to achieve the values of justice for all so that they too get their rights from the state. Of course it is considered as a form of general obligation that must be done, both Muslims with zakat and non-Muslims with jizyah. The aim is to create equilibrium in the state to avoid disparities that refer to social inequality because both Muslims and non-Muslims are both considered to be one citizen. Therefore, if the state requires jizyah upon them as Muslims pay zakat then that is very reasonable because it is categorized as part of the country's special authorization. This is the true meaning of relevance between the state and its non-Muslim citizens because they get protection because they belong to their community. In addition, it is obligatory for all communities to participate in accordance with their respective abilities to overcome the burden or budget required by each government agency in order to fulfill their obligations proportionately to the community.

\section{Second, jizyah, between rights and obligations}

Some people still consider that jizyah is a form of payment that must be made by non-Muslims to the country without any particular consequences. Of course this understanding is full of distortion because basically jizyah substantively when it is carried out will bear the consequences of both parties. With the payment of jizyah by a non-Muslim, the state is obliged to provide security guarantees covering their lives, their assets, their honor and everything related to their existence as citizens. They are entitled to protection, both from within the country itself and from outside. This was confirmed by the scholars of such as Assyairazi (393-476 AH) and Ibn Qudamah. Both said: "It is mandatory for the government to provide protection to non-Muslims, and from those who intend to evil to them, both from Muslims and from non-Muslims themselves [27]. On this basis the scholars agreed and their earthing has been evident since the days of friends 
The Prophet said that the payment of jizyah collected by the state was the consequence that the state on the one hand had to provide security guarantees to them, so that if it could not be done because of conditions and allies, then the state in this case was not allowed to collect the jizyah from non-Muslims living under his authority.

The concrete indication is what Abu Ubaidah bin Aljarrah (died $18 \mathrm{AH}$ ) had done as a Muslim warlord during the reign of Umar Bin Khattab in Syria. When he learned that Roman troops were ready and ready to fight, he sent a letter to every local Islamic government in every corner of the country. He ordered that the jizyah which they had gathered from non-Muslims be returned immediately to their owners, saying: "We deliberately return your payment, because we have heard that Roman troops are on alert and ready for combat, while you all require that we provide protection to you, and we haven't agreed yet. Therefore we return it because it is a consequence that we must keep "[28]

What Abu Ubaidah did was an indicator that jizyah is not a punishment carried out by Islamic Sharia for non-Muslims because they do not embrace Islam, but the obligation exists because they get security protection from the state. Jizyah is a form of positive participation by non-Muslims in the country with a consequence that they are entitled to protection. This is the main factor or legal basis for every country today to implement a taxpayer system for every citizen, both in Muslim-majority countries and in non-Muslim countries. It should be explained that the forms of payment made by nonMuslims, both in the time of the Prophet and in the time of Abu Bakr and several phases in the government of Umar Bin Khattab, were all categorized as jizyah, both payments were related to their existence and related to their property. But after the Islamic government area expanded, especially in the two empires, namely Persia and Rome, the separation took place. Payment obligations relating to their existence as citizens are referred to as jizyah, while payment obligations relating to their property are referred to as alKharaj or in the present language is the product tax. [29].

It has been explained that jizyah is fulfilled with the consequence of getting security guarantees from the state. Then in the time of the Prophet, non-Muslims were not burdened to defend the country or participate in war. All this happened because there were certain considerations that they were not forced to defend the country and were directly involved in the war against the enemy. Islam only burdens Muslims to defend the country in the event of war as a form of obligation in religion. Therefore Islam as a teaching that contains elements of equality requires non-Muslims to participate in covering the needs of the troops who are ready to be ready at all times to defend the country called jizyah.

It is different with the current condition, all countries in the world have applied the military system to every citizen regardless of their religious background. Not even a single Muslim-majority country does not apply this system to every citizen, both Muslim and non-Muslim. Looking at diversity 
and the present phenomenon, it will be very clear that every country in the world will not be able to distinguish its citizens by providing exceptions for not accepting candidates for army or police because of their religion, as long as they meet the qualifications specified in the law. Because if not, the country itself will experience stagnation due to the lack of people who intress with military or police positions.

Diversity that makes everyone feel connected with the state, both morally and spiritually motivates all to become members of the military or police whose consequences are to defend the people and the country. With the direct involvement of non-Muslims being part of the state security apparatus, the obligation to pay jizyah is eliminated because the consequence is that if Muslims or the state in this case no longer provide protection to them, the obligation to pay jizyah will also be nullified. Likewise with their involvement in becoming a soldier or police who at all times maintain security indicates the obligation of jizyah is abolished. In the context of Islamic law, perhaps this is the right reason so that today no non-Muslim in a majority Muslim country pays jizyah due to their involvement in maintaining security and order together with Muslims in a country, especially if the conscription system in the country it is enforced.

\section{The term Ahluzzimmah in the present context}

Ahluzzimmah is the term most often found in the literature of Islamic law when talking about the existence of non-Muslims in the midst of Islamic society. However, this term needs to be reviewed for the present, because this term in history is closely related to the process of developing Islamic da'wah itself, where when Islam for example succeeded in opening a country inhabited by mostly non-Muslims, at that time they would be given two choices as an alternative. That choice is whether they convert to Islam or whether they remain in their religion with one consequence of paying taxes (jizyah) in order to get protection from the Islamic government. But these conditions in life today have undergone a change in which every citizen has the right to participate in maintaining state security in the event of war with another country. With this basis, the ahluzzimmah system is very difficult to apply in state life, especially the relationship between the state itself and its non-Muslim citizens, so we also wonder, whether the term ahluzzimmah in the state today is still used as a symbol for non-Muslim societies, or Are there other terms that are more appropriate to interpret this matter, for example, the native population or citizens?

Actually the term ahluzzimmah for a non-Muslim citizens in relation to the state can be modified by using other terms such as natives or citizens, because one of the factors in the birth of this term is the spread of Islamic da'wah. While in the current era it can be ensured that all countries in the world have bilateral relations with other countries due to wider diplomacy so international agreements are easy to do as one of the factors supporting the propagation of da'wah without having to use an expansion path. On the other hand, when there is a war, every citizen will be burdened to maintain the existence of his country. Therefore, the relevance of the state with its people is built on the basis of the existence of the relationship of citizenship as it 
applies in the present without having to see the status of religion. Thus, the term ahluzzimmah for non-Muslim communities can be modified in essence because the term itself is not sacred in religion as has been alluded to. Even implicitly, the term of citizenship or native of a country by Syeh Naser Faried Washil (former Egyptian mufti) is actually commensurate with the term ahluzzimmah or al-Muwathin. That means that, too, there is no disparity because according to the conception of religion, non-Muslims who live in the middle Islamic society also includes indigenous people or citizens. Thus everything is equivalent, that is, one citizen, both in social and state life.

\section{CONCLUSION}

Based on the description that has been mentioned in this discussion, the following conclusions can be drawn:

1. The minority term is one of the new terms after the friction between the Ottoman dynasty government in Turkey and several European super power countries, so that the classical Islamic scholars do not use the minority term in their intellectual traditions. Nevertheless, because the term has become popular, especially in the process of writing a concept, finally the use of such terms is fine.

2. The Prophet has positioned non-Muslims as part of the state community as well as Muslims. This is a reality that they are with the Muslims is a unit that gets the rights and protection from the state.

3. In the context of Islamic law, today no one from non-Muslims in a majority Muslim country pays jizyah because of their involvement in maintaining security and order together with Muslims.

4. Islamic Jurisprudence views that non-Muslims who live in the midst of Islamic societies are included as native residents or citizens as well as Muslims. All are considered as one citizen, both in social and state life. Allah knows best.

\section{REFERENCES}

[1] Habib, Kamal Said, Nahwa Binain Islamiyin li Mustalah al-Akalliyah, (Kairo: Majalah al-Bayan, edisi. 90. Juli 1995), h.97.

[2] Ahlul Kitab adalah sebuah kelompok agama yang mempunyai kitab suci yang bersumber dari langit (Allah Swt.) seperti Yahudi dan Nasrani.

[3] Non Muslim harbi adalah seorang non Muslim yang tidak mempunyai hubungan perjanjian sedikit pun dengan pemerintah Islam.

[3] Non Muslim muahad adalah seorang non Muslim yang mempunyai perjanjian damai antara negara asalnya dengan pemerintah Islam.

[4] Mansur, Ali Ali, Assyariah al-Islamiyah wa al-Kanun Addauli al-Am, (Kairo: Almajlis al-A'la li Assyuun al-Islamiyah, 1965), h.98. lihat 
juga: Asyur, Said Abd. Fattah, Alharakah Assalibiyah (Kairo: al-Anjlo Almasriyah, 1975), h.29.

[5] Yang demikian itu adalah pendapat mayoritas ulama termasuk mazhab Hanafi, Syafi' dan Zaidiyah.

[6] Yang demikian itu adalah pendapat sebahagian ulama termasuk mazhab Hanbali.

[7] Albaz, Mustafa Muhammad, Jinsiah Abna al-Um al-Misriah, (Kairo: Dar al-Wisam, 2003), h.13. lihat juga: Riyad, Fuad Abd. Mun'im, Mabadi al-Kanun Addauli al-Khas, (Kairo:Dar Annahdah, 1996), h.109.

[8] Hadits riwayat Abu Daud.

[9] Mahmasani, Subhi, al-Kanun wa al-Alakah Addauliyah fi al-Islam, (Bairut: Dar il-Ilmi li al-Malayin, 1392), h.101.

[10] Huwaidi, Fahmi, Muwatiinun La Azzimmiyun, (Kairo: Dar Assyuruk, tt.), h.106.

[11] Fuad Abd. Mun'im, Mabadi al-Kanun Addauli al-Khas, (Kairo: Dar Annahdah, 1996), h. 6, 9.

[12] Ibid.h.19.

[13] Wasil, Faried Muhammad, al-Madkhal al-Wasit Lidirasah Assyariah alIslamiyah wa al-Fikhi al-Islami, (Diktat pasca sarjana Universitas alAzhar Kairo Mesir), h.43.

[14] Aljauziyah, Ibnu Qayyim, Ahkam Ahli Azzimmah, (Kairo: Dar al-Hadits, 2003), h.30, 31.

[15] Assarakhsi, Almabsut, (Bairut: Dar al-Ma'rifah, 1989), jld.10. hal.78. Hamidullah, Muhammad, Majmuah Alwatsaik Assiyasiyah, (Bairut: Dar Annafa'is, 2001), h.61.

[16] Zaidan, Abdul Karim, Bahsun fi Mas'alah al-Akaliyyat Gairi alMuslimah wa al-Ajanib fi Assyariah al-Islamiyah, (Kairo: Majallah Alhukuk, edisi.3.1983), h.308.

[17] Addimyatiy, Ianatu at-Talibin, (Bairut: Dar Alfikri, tt), jld.4.h.208.

[18] Alkhattab, Mawahibu al-Jalil fi Syarhi Mukhtasar al-Khalil, (Bairut: Dar al-Fikri, 1992), Jld.10.h.5.

[19] Hadits riwayat Albaihaki.

[20] Azzailai, Tabyin al-Hakaik, (Dar al-Kitab al-Islami, tt), jld.9.h.273.

[21] Almawardi, Abul Hasan, al-Ahkam Assulthaniyah, (Bairut: Dar al-Fikr, tt), h.143.

[22] Arnold, Sirt Thomas, Adda'wah Ilal Islam, (Kairo: Maktabah Annahdah Almasriyah, 1957), h.77.

[23] Ibid.h.79.

[24] Huwaidi, Fahmi, Muwatiinun La Azzimmiyun, (Kairo: Dar Assyuruk, tt.), h.138.

[25] Annawawi, Muhyiddin, Almuhazzab Ma'a Syarhihi, (Jeddah: Maktabah al-Irsyad, tt), jld.21.h.338.

[26] Abu Yusuf, al-Kharaj, (Kairo: Al-Matba'ah as-Salafiah, 1352 H), h.239. Badawi, Ismail, Ikhtisasat Assulthah Attanfiziyah fi Addaulah alIslamiyah wa Annuzum Addusturiyah al-Maasirah, (Kairo: Dar Annahdah al-Arabiah, 1993), h.175.

[27] Denit, Danial, tarjamah Fauzi Fuhaim, al-Jizyah wa al-Islam, (Kairo: Dar Maktabah al-Hayah, tt), h.19. 
[28] Zaidan, George, Tarikh Attamaddun al-Islami, (Kairo: Dar al-Hilal, tt), jld.1.h. 227-228.

[29] Albalaziri, Futuhul Buldan, (Bairut: Dar Alkutub al-Ilmiah, 1991), h.185-186. 